\title{
THE CHALLENGE OF DEMOCRACY IN INDONESIA: THE CASE OF SALAFI MOVEMENT
}

\author{
Din Wahid \\ Syarif Hidayatullah State Islamic University, Jakarta \\ dinar68@yahoo.com
}

\begin{abstract}
In spite of strong support of the majority of Muslims in Indonesia to democratic system, there are small numbers of Muslim who reject the democratic system. To name a few, I can mention here some groups of Muslims who oppose the democracy, such as Hizbut Tahrir Indonesia (HTI), Majelis Mujahidin Indonesia (MMI) and Salafis. These groups maintain that democracy is against Islam, because Islam does not recognize democracy. Democracy as symbolized by "the power of people" contradicts the basic doctrine of Islam concerning the sovereignty. In Islam, they maintain, the power or sovereignty belongs to God only. This essential concept creates various consequences dealing with governance of the ruled. This paper discusses the views of Salafis in Indonesia on the democracy. Despite their resistance of democracy, the Salafis consider a ruler resulted from democracy is valid, and Muslims should obey him: they are not allowed to criticize him publicly, and are not allowed to rebel against him.
\end{abstract}

Keywords: Salafis, manhaj, mushāwarah, democracy, ahl al-ḥall wa al-'aqd, kufr.

\section{INTRODUCTION}

Since 1998, following the collapse of Suharto regime, Indonesia has increasingly become one of the largest democratic countries in the world. Since then, Indonesia has carried out three general elections (1999, 2004 and 2009), which were considered as free general elections by foreign observers. In addition, during the Reformation era, Indonesia has made many reforms that support democratic system including freedom of expression and political reforms.

In spite of strong support of the majority of Muslims in Indonesia to democratic system, there are small numbers of Muslim who reject the democratic system. To name a few, I can mention here some groups of Muslims who oppose the democracy, such as Hizbut Tahrir Indonesia (HTI), Majelis Mujahidin Indonesia (MMI) and Salafis. These groups 
maintain that democracy is against Islam, because Islam does not recognize democracy. Democracy as symbolized by "the power of people" contradicts the basic doctrine of Islam concerning the sovereignty. In Islam, they maintain, the power or sovereignty belongs to God only. This essential concept creates various consequences dealing with governance of the ruled. This paper discusses the views of Salafis in Indonesia on the democracy. I will start this discussion with a brief overview on historical development of Salafi movement in Indonesia, followed by Salafis views of democracy. Discussion on the democracy will be divided into three sub-topics: 1). Salafis' view on Islam as a comprehensive way of life; 2) Salafis' view on democracy; and 3). Salafis' view on obedience to ruler. This paper will be ended with concluding remarks.

\section{MATERIALS AND METHODS}

This research is basically a fieldwork study in 14 Salafi pesantrens (Islamic boarding schools) conducted in two periods: from mid-August 2008 to midApril 2009 and from mid-December 2009 to mid-September 2010. It is through this study that I collected data using observation and in-depth interviews that made up primary sources. Besides, I also used documentary sources in the forms of CDs and DVDs that record the Salafi's lectures, leaflets and booklets.

Based on the characteristics of this study, I used an anthropological approach. During my stay at these pesantrens, I observed closely all activities performed by santris (students) as well as participated in some activities, such as collective prayers in the mosque, attending religious lectures, attending the classrooms, and even having meals together with the teachers. I had an opportunity to interview with director (mudir), teachers (ustadhs), and administrative staffs. In addition, I also interviewed people surrounding pesantrens and the leaders of Muslims organizations as well. These organizations include Muhammadiyah, Nahdlatul Ulama, Persatuan Islam and Persatuan Umat Islam. Through this approach it is expected that Salafi's responses to the concept of democracy can be portrayed accurately and proportionally.

\section{RESULTS AND DISCUSSION}

\section{A. Salafism Definition}

To start the discussion, I would like begin with making clear distinction between Salafiya movement and contemporary Salafi movement. Salafiyya movement is a movement that calls for Islamic reformism with the return to the Qur'an and hadith. This movement originated in Egypt in the late $19^{\text {th }}$ century and advocated by the three pioneers of Islamic reformism, Jamal al- 
Din al-Afghani, Muhammad 'Abduh and Rashid Ridla. ${ }^{1}$ However, since the last two decades, Indonesia has witnessed the emergence of a new Salafi movement. This new movement concerns the purification of religious thought and practices with the slogan "the return to the Qur' an and hadith". This movement contends that the return to these fundamental sources of Islam in insufficient, and hence, the Salafi movement adds the third source of Islamic doctrines, that is the example of the al-Salaf al-șa lih, the first three generations of Muslims. ${ }^{2}$ They call themselves as "Salafi", meaning a person who follows the Salafi manhaj (the path of the Salaf).

The emergence of the contemporary Salafi movement in Indonesia in the late 1980s was closely linked to the development of the religiopolitical ambition of the Saudi government. Since its creation in the mideighteenth century and its reconstruction in the early twentieth century, the Saudi state has adopted Wahhabism as the state's model of Islam. The Saudi government has enjoyed Wahhabi support for social and political stability in the country as its "ulama have always issued fatwa (religious opinion) legitimizing the government policy. However, within the Muslim world, the Saudi government encountered serious challenges from Jamal Abdul Nasser of Egypt with his Arab Socialism in 1960s, and from the Shi' ism of the Iranian revolution in the late 1970s.

Supported by the oil boom in the 1970s, the Saudi government attempted to export its Wahhabi Islam to the Muslim world in order to halt the influence of its rivals: Nasser's Arab socialist and Shi'ism. The efforts included the creation of the Organization of Islamic Conference (OIC) in 1957, followed by the establishment of the Rābițat al-'Ālam al-Islāmī (RAI, the Muslim World League) few years later. While the first organization was aimed at formulating foreign policy for Muslim countries, the latter was intended to disseminate Saudi's variant Islam. Through the Rabita, the Saudi government provided large amount of money to the Muslim world for different purposes such as building mosques, scholarships and supporting preachers. It was within this effort that the Saudi government offered scholarships for Indonesian students to study in Saudi universities. In Indonesia, the scholarships were channeled through Saudi-linked institutions, such as the Dewan Dakwah Islamiyah Indonesia (DDII, or Dewan Dakwah) and Lembaga Ilmu Pengetahuan Islam dan Arab (LIPIA). The pioneering Salafis in Indonesia were awarded scholarships by the Dewan Dakwah and LIPIA.

In Indonesia, contemporary Salafis found fertile ground for their movement. Following the 1974 riot by university students, well known as

\footnotetext{
${ }^{1}$ W. Ende, "Salafiyya”, Encyclopedia of Islam, Vol. 8 (Leiden: Brill, 1995), 900.

${ }^{2}$ See, for example, 'Abd al-Ḥakim bin Amir Abdat, Lau Kaana Khairan Lasabaquunaa Ilahi (Jakarta: Pustaka Mu'awiyah bin Abi Sufyan, 2007); Yazid bin Abdul Qadir Jawas, Mulia dengan Manhaj Salaf (Bogor: Pustaka At-Taqwa, 2008), 55-158.
} 
the Malari case, in 1978 the government promulgated a new rule concerning student activities on campus. The new rule, called Normalisasi Kehidupan Kampus/Badan Koordinasi Kampus (NKK/BKK, Normalization of Campus Activities/Campus Coordinating Body), restricted the political engagement of students. ${ }^{3}$ Responding to this new regulation, in the early 1980s some students turned to religious activities, particularly to discussions of Islamic doctrines. Starting from the Salman mosque of the Bandung Institute of Technology (ITB), enthusiasm to study Islam soon became widespread in other campuses such as the Bogor Institute of Agriculture (IPB), Bogor, West Java, the University of Indonesia (UI) in Jakarta, Gadjah Mada University (UGM) in Yogyakarta, and the University of Hasanuddin (Unhas) in Makassar, South Sulawesi. The activists developed the so-called usra (lit. family) in their recruitment and study model. ${ }^{4}$

The Dewan Dakwah merits mention in this regard. Banned by the government from any political activities, the Dewan Dakwah figures, particularly Mohammad Natsir, took this opportunity to disseminate their ideas through the campuses. A.M. Luthfi, former secretary of Natsir, explained that the campus was the only free place from observation. ${ }^{5}$ The Dewan Dakwah encouraged Muslim intellectuals, notably Imamuddin Abdul Rahim, Ahmad Sadili and Nukman, to hold the Latihan Mujahid Dakwah (LMD, Training for Preachers) at ITB, inviting student activists from other campuses. LMD was a special training for preachers, in which students were trained in a comprehensive Islam (Islam $k \bar{a} f f a$ ) in which Islam is perceived not only as a doctrine of worship but also as a doctrine of society, economics and politics. ${ }^{6}$ These activists later developed similar programs in their own campuses.

In 1980s, Muslims observed the swing of the political pendulum of the New Order regime. In the first half of the decade, Suharto proposed the state ideology Pancasila, as the sole foundation of all organizations, including mass organizations and political parties. This idea was profoundly opposed by Muslims figures, and culminated in the bloody Tanjung Priok (North Jakarta) tragedy in 1984 in which hundreds of lives were lost and caused injury to many others. Repressive measures from the ruler continued until all Muslim organizations had no choice but to accept the ruler's demand. The two largest Muslim organizations, Nahdlatul Ulama (NU) and

\footnotetext{
${ }^{3}$ Noorhaidi Hasan, Laskar Jihad: Islam, Militancy, and the Quest for Identity in Post-New Order Indonesia ( New York: Cornell University, 2006), 44.

${ }^{4}$ The term 'usra' literally means 'family'. This method was adopted by the Ikhwanul Muslimin movement in Egypt in order to avoid the ruler's repressive measures on the organization. Usually an usra consists of 5 to 15 participants under the leadership of năqib. Indonesian activists learned the method from their counterparts in Malaysia, where they had encountered repression from the government. See, Abdul Syukur, "Gerakan Usroh di Indonesia, Kasus Peristiwa Lampung 1989,” Master Thesis (Jakarta: Universitas Indonesia, 2001), 41-44.

${ }^{5}$ Interview with AM. Lutfi, Jakarta, September 12, 2008.

${ }^{6}$ Ali Said Damanik, Fenonema Partai Keadilan: Transformasi 20 Tahun Gerakan Tarbiyah di Indonesia (Bandung: Teraju, 2002), 68-69.
} 
Muhammadiyah, for example, accepted Pancasila as their foundation in 1984 and 1985, respectively. The reluctant organizations were dissolved. Having secured its ideology, the government moved to accommodate Muslims' interests. This tendency was apparent in Suharto's approval of the promulgation of Religious Court in 1989, the launch of the first Islamic Bank in Indonesia, the Bank Mu'amalat Indonesia (BMI), and the establishment of Ikatan Cendekiawan Muslim Indonesia (ICMI, Association of Indonesian Muslim Intellectuals). Suharto himself underwent a pilgrimage during this period.

It was within this socio-political setting of Indonesia that the Salafi movement started to surface. The Salafis began in the late 1980s when enthusiasm for studying Islam had grown among university students. As Hasan has shown, this enthusiasm provided a fertile soil for Islamic global movements such as Ikhwanul Muslimin and Hizbut Tahrir in Indonesia. ${ }^{7}$ The Salafis targeted the university students in Yogyakarta. It was Abu Nida (Chamsaha Shofwan) who initiated the Salafi da'wa among the university students. In this initial period, Abu Nida cooperated with some activists of Ikhwanul Mulilimin, such as Abu Ridlo, in spreading the Salafi doctrines, championing the combined Salafi-Ikhwani slogan "Aqidah Salafi, Manhaj Ikhwani" ("Salafi creed, Ikhwani method"). ${ }^{8}$ Having gained a significant number of followers, Abu Nida independently managed his own religious circles around Gadjah Mada University, such as at the Mardiyah and Mujahidin mosques near the Faculty of Medicine and Faculty of Engineering of Gadjah Mada University. In this city, Abu Nida collaborated with his companions, Ahmas Faiz Asifuddin and Aunurrafiq Ghufran. Like Abu Nida, Asifuddin and Ghufran were the cadres of Dewan Dakwah and alumni of the University of Imam Ibn Su'ud in Riyadh. They managed the Salafi halqas and dawras in Yogyakarta. The students were also encouraged to study Arabic.

The return of three new graduates, Ja'far Umar Thalib, Yazid Abdul Qadir Jawwas and Yusuf Usman Baisa, to Indonesia gave more impetus to the Salafi da'wa initiated by Abu Nida. These people were assigned to teach at the pesantren al-Irsyad in Tengaran, Salatiga, Central Java. Although their presence at the pesantren raised opposition from the existing teachers, the Salafi figures successfully changed the pesantren's orientation to Salafism. The pesantren soon became the center of Salafi da'wa, attracting many Salafi figures. Many Salafi figures attended the Salafi dawras in the pesantren. However, friction emerged among these figures. The conflict was triggered by the replacement of Thalib by Baisa as the director of the pesantren. Following this replacement, Thalib left the

\footnotetext{
${ }^{7}$ Hasan, Laskar Jihad, 45.

${ }^{8}$ Hasan, Laskar Jihad, 52-52.
} 
pesantren and established his own pesantren, Ihya al-Sunna, in Degolan, Kaliurang, Yogyakarta in 1994.

It was from the pesantren al-Irsyad in Tengaran that other Salafi pesantrens started to spread across the country. They have emerged in several cities in Java and on some of the outer islands. Thus, in West Java we find, for example, Minhaj al-Sunnah in Bogor, Ihya' al-Sunnah in Tasikmalaya, Al-Nur al-Atsari in Ciamis, Al-Sunnah and Dhiya' al-Sunnah in Cirebon; in Yogyakarata, we find Ihya al-Sunnah, Anshar al-Sunnah, Bin Baz, and Jamilurrahman; in Central Java, we find al-Irsyad in Tengaran, Imam Bukhari in Solo; in East Java, we find STAI Ali ibn Abi Thalib in Surabaya and al-Furqan in Gresik. In the outer islands we also find Anshar al-Sunnah and SDIT Fajar Ilahi in Batam, Kepulauan Riau, Sumatera; in South Sulawesi we find Anshar al-Sunnah and Wahdah Islamiyyah in Makassar; pesantren Abu Hurairah in West Nusa Tenggara, Lombok island.

The creation of Forum Komunikasi Ahlusunnah wal Jama'ah (FKAWJ, Communication Forum for the Followers of Sunna and Jama'a) in 1999, followed by its paramilitary wing, the Laskar Jihad, that called Muslims for jihad in Ambon and Poso made the conflict between Salafis more visible. Although Thalib's call for jihad was supported by fatwas from many Salafi shaykhs in Saudi Arabia and Yemen, it was sharply criticized by his opponents. Asifuddin, for example, criticized the jihad as invalid as it deviated from the true Salafi doctrine, arguing that the most fundamental doctrine of the Salafi manhaj is obedience to the ruler. ${ }^{10}$ The Laskar Jihad was then dissolved only a few days after the tragedy of the first Bali bombings in October 2002.

The Laskar Jihad's closure left friction between Thalib and his followers. According to his followers, Thalib had deviated from the spirit of Laskar Jihad. The case of Kebon Cengkeh, in which the Laskar Jihad had confronted the army, resulting in the deaths of many followers of the Laskar raised worry among its leading figures. This had showed how the Laskar had moved from fighting against non-Muslims to confronting the army. ${ }^{11}$ Thalib was also charged with having gone too far beyond his mandate by dispatching the Laskar Jihad to Ngawi, East Java, to deal with gambling activities. This action resulted in conflict with both local villagers and activists of the political party. ${ }^{12}$ As a result, Thalib was left by his closest comrades, including the Laskar's vice commander, Muhammad alSewed. Currently, the conflict between them still exists.

The Salafis have developed some basic ideas. Bernard Haykel summarizes those ideas as follows: 1) going back to pristine Islam as

\footnotetext{
${ }^{9}$ Ja'far Umar Thalib, “Menepis Rekayasa Fatwa Seputar Jihad di Maluku”, Salafy, 34 (2000), 8-9.

${ }^{10}$ Interview with Ahmas Faiz Asifuddin, director of Pesantren Imam Bukhari, Solo, February 21, 2009.

${ }^{11}$ Interview with Ahmad Halim, former activist of Laskar Jihad, Yogyakarta, January 19, 2009.

${ }^{12} \mathrm{http} / / /$ majalah.tempointeraktif.com/id/arsip/2001/12/26/LU/mbm.20011226.LU86755.id.html, accessed on April 13, 2011.
} 
prescribed in the examples of al-Salaf al-sālih; 2) stressing on certain teaching of tawhìd (rubūbiyya, ulühiyya and al-asmā' wa al-sifât); 3) fighting shirk (polytheism); 4) declaring that the Qur'an, hadith and the consensus of the Companions (ijmā' al-sahaba) are the only valid sources of Islamic law; 5) taking away all religious innovations from Muslim community; and 6) advocating literal interpretation of the Qur'an and hadith to guide Muslims in their life. ${ }^{13}$ Added to these characteristics is absolute honor to the companions. Though the Salafis do not believe in their infallibility (ma'șum), the Salafis prohibit Muslim from insulting them. ${ }^{14}$

\section{B. Salafism and Democracy}

Islam as a comprehensive way of life

Salafis' view on the politics derives from their understanding Islam. Unlike other groups of Muslims who contend the Islamic doctrines cover aqüda (creed) and ibāda (rituals) only, the Salafis believe in comprehensiveness of Islam (shumūliyat al-Islam). The Salafis believe that Islam is an allencompassing religion that covers all aspects of life: creed, rituals, social norms, economics, and politics. This belief is based on the Qur'anic verse [5:3] that reads: "This day I have perfected your religion for you, completed my favour upon you and have chosen for you Islam as your religion". Based on this Qur'anic verse, the Salafis refute secularism that separates religion from politics. According to Salafis, politics is inseparable from religion; the politics is a part of religion. ${ }^{15}$

\section{Theocracy versus Democracy}

Based in this basic doctrine, the Salafis elaborate their theory of power. The Salafis believe that the power, governance or political authority belongs to God only, and all creatures on the earth, including human beings, must submit to God's law. The task of human beings is to implement God's law as prescribed in the holy Qur'an and hadith. Human beings have no right to create new laws contradicting to divine law. This view is based on the the Qur'anic verse [3:26] that reads: ${ }^{16}$

"Say: Oh Allah! Lord of power (and rule), Thou givest power to whom Thou pleasest, and Thou strippest off power from whom Thou pleasest. Thou endues with honour whom Thou pleasest, and Thou bringest low whom Thou pleasest. In Thy hand is all good. Verily, over all things Thou hast power".

${ }^{13}$ Bernard Haykel, "On the Nature of Salafi Thought and Action", Global Salafism, ed. Roel Meijer (London: Hurst and Company, 2009), 38-39.

${ }^{14}$ Interview with Aunurrafiq Ghufran, director of pesantren al-Furqan, Gresik, 26 December 2009.

${ }^{15}$ Muhammad Umat As-Sewed, "Islam Mengat ur Sistem Negara”, Salafy, 40 (2001), 13.

${ }^{16}$ Thalib, "Menyoal Demokrasi", Salafy, 30 (1999), 4. 
This means that, according to Salafism, Islam does not support democracy but theocracy. In another words, Islam is incompatible with democracy. According to this theocracy, the human beings' power derives from God's power, and then God endows His power to elected people in order to govern the earth according to His laws. This doctrine brings about some consequences: human beings are not allowed to create any law contradicting to His laws; the ruler has to implement God's laws prescribed in the holy Qur'an and hadiths; the ruler is not allowed to surrender to the will of majority, since the majority can mislead and deviate from the truth. The truth, according to Salafis belongs to God, and the task of the ruler is to maintain this truth. Here, the Salafis reject the slogan of democracy that equates "people's will" to "God's will".

One of crucial issue dealing with democracy is general election as a method of assigning the ruler. In democratic countries, including Indonesia, general election is considered as the best way to elect the rulers: president, governors, majors, and people representatives. The question is how Salafis choose the ruler. In line with notion of theocratic system, Salafis do not support the general elections. They argue general election as a manifestation of democratic system considers the quantity of the people only, and at the same time, ignores their quality. In democracy, the value of kyai, for example, is the same as that of prostitute, because they have similar vote, one vote.

Rejecting general election as a method of appointing the ruler, the Salafis proposes another mechanism, by establishing the ahl al-hall wa al'aqd (people who loose and bind). The ahl al-hall wa al-'aqd consists of knowledgeable people in different fields: religion, defense, politics, economics, social, and cultures. It is not clear how Salafis select people to become members of the ahl al-hall wa al- 'aqd. However, once the members of the ahl al-hall wa al-'aqd are selected, they have crucial task to appoint the ruler. When the ruler deviates from the right track, the member of the ahl al-hall wa al-'aqd also have right to replace the ruler with another. Thus, according to Salafis, it is not the people who appoint and depose their ruler, but the ahl al-hall wa al-'aqd. Through this mechanism, not all people participate in process of the election of the ruler. ${ }^{17}$ Because of this believe, the Salafis do not go to the poll to vote.

The concept of the ahl al-hall wa al-'aqd proposed by Salafis makes a clear distinction between democracy and shürā (consultation). While many Muslims believe that shērà is similar to democracy, the Salafis argue they are different. Democracy engages all people to take part in the process of the selection, while shürā involve few people only.

${ }^{17}$ Thalib, "Menyoal Demokrasi”, 6. 
Furthermore, the Salafis elaborate damage caused by general election. The damage, among other things, includes: ${ }^{18}$

1. General election is considered as an act of polytheism, because it creates a new idol, the majority of the voters. Moreover, it also makes new legislation on the basis of the majority, while in Islam, the legislator is God.

2. General election leads Muslims to disregard the doctrine of al-wala wa al-barā' (loyalty and disavowal). The doctrine suggests Muslims to love their fellow Muslims and hate non-Muslims and work for the sake of God and His Messenger. While in the general election, Muslims work together with non-Muslim to choose and decide their representatives and ruler.

3. In some cases, general election is supported by funds from Western countries (the Jews and Christians), in order to infiltrate their interest.

4. People engaged in the general election in fact insults Islam because they give non-Muslims opportunity to accuse Islam of being incomplete as it has no doctrine to create a just and prosperous society.

5. General election creates money politics, which is not allowed in Islam.

6. General election fragments Muslims, and creates hizbiyyah or fanaticism to party and leader, while Islam teaches Muslims to show their love to the prophet.

\section{Obedience to the ruler}

Although not agreed to by all Salafis, the doctrine of people's obedience to the ruler is a pivotal Salafi doctrine in relation to Muslims' attitudes towards the government. The idea of submission to the government is almost absolute and can only be ignored for very fundamental reason of faith. There is, no doubt, a small group of Salafis who object to this doctrine and who support the takfir idea as discussed above. This objection, however, does not detract from the significance of the dominant Salafi doctrine concerning allegiance to the ruler. Madawi al-Rasheed has noted that in Saudi Arabia, the doctrine of obedience to the ruler dates back to 1929 after the ikhwan's rebellion against the Saudi ruler, Abd al-Aziz ibn Su'ud. Ibn Su'ud defeated his own rebellious comrades in the battle of alSibla and repelled them to the neighboring Gulf states, which were under British rule. Soon after quelling the rebellion, the Saudi clerics developed the doctrine of obedience to the ruler in the home country. Any attempt to

${ }^{18}$ Muhammad Umar As-Sewed, “Beberapa Kursakan Pemilu”, Salafy, 30 (1999), 8-15. 
oppose him was deemed khurūj 'alä al-hākim, rebellion against the ruler. ${ }^{19}$ This doctrine of loyalty is supported by many datils from the Qur'an, the prophetic tradition and the examples of the pious predecessors, the al-Salaf al-șalih.

In Salafi doctrine, Qur'anic verse 4: 59 contains the main argument for the submission to the government. This verse states that Muslims should obey God, the Messenger and their rulers (wali al-amr). Both government and 'ulama are included in the category of 'ruler'. ${ }^{20}$ Another Qur'anic injunction, verse 4: 83, tells us that Muslims should always refer back to the prophet and the ruler. Unlike the submission to God and His messenger, which are absolute, obedience to the ruler is conditional in so far as a ruler's command does not contradict the commands of God. Should the ruler command his people to commit sinful acts, however, Muslims are told they are not allowed to execute his order. ${ }^{21}$

In addition to the above reference, there are a number of prophetic sayings that command Muslims to obey a ruler and not to rebel against him even in cases where he is a tyrant, repressive or acts like the devil. ${ }^{22}$ The prophet relates submission to the ruler to submission to himself: loyalty to the ruler equates devotion to the prophet. ${ }^{23}$ The prophet also tells that a Muslim who dies being disloyal to the government dies in a state of jāhiliyyah (as if in the age of ignorance), as according to Ibn Taymiyya, rebellion against the ruler is a jāhiliyyah tradition. However, Salafis follow the example of the pious predecessors and quote the story of Ahmad ibn Hanbal who, despite being tortured by his ruler, remained loyal to him. ${ }^{24}$

With reference to the sources mentioned above, Salafis contend that Muslims are not allowed to rebel against a ruler as long as he allows Muslims to perform their religious duties, such as performing the five prayers, fasting during Ramadan, and paying alms. There are only two conditions that permit Muslims to rebel: if a ruler demonstrates his kufr (unbelief in God) and if he does not perform his prayers. ${ }^{25}$ However, it is a complicated matter to decide whether or not a ruler is a kāfir (unbeliever). This status cannot be indicated by his sayings alone because his sayings and his acts may not constitute the essence of his belief. Furthermore, a ruler's

\footnotetext{
${ }^{19}$ Madawi Al-Rasheed, "The Minaret and The Palace: Obedience at Home and Rebellion Abroad”, Kingdom without Borders, ed. Madawi al-Rasheed (London: Hurst and Company, 2008), 203.

${ }^{20}$ In spite of the minor difference in interpreting the term "waliyy al-amr minkum" (ruler from you), the Salafis agree that the term includes the ruler and the "ulamā. See, "Kewajiban Mentaati Penguasa dalam Perkara yang Baik (Tafsir Surat An-Nisa' 59)”, Salafy, 5:7 (2005), 44-46.

${ }_{21}$ Abu Abd al-Rahman Fauzi al-Atsari, Meredam Amarah terhadap Pemerintah (Pekalongan: Pustaka Sumayya, 2005), 49.

${ }^{22}$ A famous hadith from Hudhaifa ibn Yaman says that a Muslim should listen to and obey his ruler even if the ruler intimidates him and appropriates his wealth. The hadith is narrated in the two foremost reliable hadith books of Sahīh al-Bukhārī and Sahịh Muslim. See al-Atsari, Meredam Amarah, 56.

${ }^{23}$ Al-Atsari, Meredam Amarah. 53. See also Yazid bin 'Abd al-Qadir Jawās, Syarah Aqidah Ahlus Sunnah wal Jama'ah (Bogor: Pustaka Imam Syafi'i, 2006), 573.

${ }^{24}$ Al-Atsari, Meredam Amarah, 68.

${ }^{25}$ See “Akhlak Kaum Muslimin Menghadapi Penguasa yang Dhalim,” Salafy, 5:7 (2008), 60.
} 
tyrannical and evil acts cannot make him a kāfir. It is the duty of hadith 'ulama to decide whether or not a ruler may remain Muslim; ordinary people cannot accuse a ruler of being kāfir. ${ }^{26}$

Salafis believe that fighting a Muslim ruler will result in more damage than the ruler himself ever could do. ${ }^{27}$ This appears to contradict the principle of commanding right and forbidding evil but Salafis argue that evil cannot be eliminated though committing other evil acts. Moreover, when applying the principle the potential gains and damages should be measured. In fact, Salafis have developed various guidelines for its implementation: first, if the application of commanding right and forbidding wrong outweighs the damage its application would cause, then it is demanded by religion. Second, and by contrast, if the application of the principle creates more damage than benefit, it is considered unlawful. Third, if the benefit is equal to the damage, the application of the principle is neither demanded nor prohibited so it is permissible. These guidelines are in line with the more general principle in Islam of "avoiding damage is preferable to acquiring benefit."

The Salafis have set up practical guidelines for the relationship between the ruler and the ruled: Muslims must honour the ruler, not criticize him publicly and not speak about his weaknesses. In addition, rather than advising a ruler in the public space, Muslims are required to advise him covertly. Muslims are obliged to display their support for their ruler by performing their religious duties such as paying alms (zakāt), performing the pilgrimage and waging jihad. ${ }^{29}$ It should be noted that for Salafis, jihad is only valid if instructed by a legitimate imam. Muslims should also abide by the government's decision concerning the arrival of Ramadan and the dates of the festivals of İd al-Fițr and İd al-Aḍhā. ${ }^{30}$ As it happens, these important Islamic events have been the cause of recurrent disagreement among Indonesian Muslims. For many years, Muslims have used different methods to decide when the beginning of Ramadan should be. Similarly, different Muslims have celebrated Īd al-Fițr on different days. In order to avoid this kind of disagreement, Salafis opt to follow the Indonesian government's decision when Id al-Fițr should be celebrated, and they follow the decision of the Saudi government when the festival of İd alAdha should be held. In the last case, they argue that the celebration of İd al-Adha relates to the ritual enacted during the pilgrimage, which is performed in Saudi Arabia and thus the Saudi Government should decide

\footnotetext{
${ }^{26}$ Ja'far Umar Thalib, “Sikap Politik Ahlus Sunnah”, Laskar Jihad, 20 (June 2002), 5. Also, interview with Ahmas Faiz Asifuddin, the director of pesantren Imam Bukhari, Solo, February 21, 2009.

${ }^{27}$ Jawas, Syarah 'Aqidah, p 573.

${ }^{28}$ Yazid bin Abdul Qadir Jawas, Amar Ma'ruf Nahi Munkar Menurut Ahlus Sunnah wal Jama'ah (Bogor: Pustaka At-Taqwa, 2009), 214-225.

${ }^{29}$ Al-Rasheed, "The Minaret and The Palace," 205.

${ }^{30}$ Al-Atsari, Meredam Amarah, 232-246.
} 
when the ritual should be held. İd al-Adha occurs on the $10^{\text {th }}$ of Dhulhijja, the last month of the Islamic calendar when large numbers of Muslims from all over the world perform the pilgrimage. The pilgrims gather in 'Arafa to perform the wuqu$f$, one of the hajj rituals on the $9^{\text {th }}$ of Dhulhijjah or one day before the celebration of $\bar{I} d$ al-Adha. As the wuqu $f$ is held in Saudi Arabia, the Saudi government has the authority to decide on its date. ${ }^{31}$

To participate in demonstrations is perceived as bid'a. It contradicts the general principle that evil cannot be countered by another evil. Usually, demonstrations involve both women and men and this mixing of the sexes is not allowed. Moreover, large crowds may be seen as a possible catalyst and provoke other followers to act violently and to rebel against the legitimate ruler. For Salafis, participants in demonstrations find it difficult to control their statements and acts, which may humiliate the government and result in damage. ${ }^{32}$

\section{CONCLUSION}

Although the majority of Muslims in Indonesia endorse democracy, there is small number of Muslims who reject democracy on the basis of religious doctrines. As conceived by Salafis, democracy is against Islam, and therefore Islam is incompatible with democracy. However small number of them reduces people's participation in democracy. In an era of political literate, religious-based opposition to democracy is more dangerous than opposition based on other reasons. However, Salafis are inconsistent in their opposition to democracy by introducing their doctrine of loyalty to the ruler. Once the ruler comes into power, regardless his method in obtaining the power (general election, and hence, democracy), the ruled has to honour and accept him as a legitimate ruler.

\section{REFERENCES}

Abaza, Mona. Islamic Education, Perceptions and Exchanges: Indonesian Students in Cairo. Paris: Cahier d'Archipel 23, 1994.

Abdat, Abdul Hakim bin Amir. Al-Masà'il (Masalah-Masalah Agama), Vol. 1. Jakarta: Darus Sunnah Press, 2005.

Hukum Tahlilan. Jakarta: Pustaka Mu'awiyah bin Abi Sufyan, 2009.

-------. Lau Kaana Khairan la Sabaquunaa Ilaihi. Jakarta: Pustaka Mu'awiyah bin Abi Sufyan, 2007.

------. Risalah Bid'ah. Jakarta: Pustaka Mu'awiyah bin Abi Sufyan, 2004.

${ }^{31}$ Interview with Ahmas Faiz Asifuddin, Solo, February 21, 2009. Interview with Mubarok Bamu'allim, Surabaya, December 23, 2008.

${ }^{32}$ Syeikh Su'ayyid ibn Hulaiyyil al-Umar, "Demonstrasi,...Solusi atau Polusi?", Adz-Dzakirah, 5: 5 (22 Rabi al-Thani 1428), 10-15. 
Al-Rasheed, Madawi. "The Minaret and The Palace: Obedience at Home and Rebellion Abroad", Kingdom without Borders, ed. Madawi alRasheed. London: Hurst and Company, 2008.

-------. Contesting the Saudi State: Islamic Voices from a New Generation. Cambridge: Cambridge University Press, 2007.

Azra, Azyumardi. The Origins of Islamic Reformism in Southeast Asia. Leiden: Asian Studies Association of Australia and KITLV, 2004.

Bruinessen, Martin van. "Kitab Kuning: Books in Arabic Script used in the Pesantren Milieu," BKI, 146 (1990): 226-269.

------. "State-Islam Relations in Contemporary Indonesia: 1915-1990," State and Islam, ed. C. van Dijk and A.H. de Groot. Leiden: Research School CNWS, 1995.

------. "Genealogies of Islamic Radicalism in Post-Suharto Era", South East Asia Research, 10:2 (2002): 117-154.

Hasan, Noorhaidi. "Education, Young Islamist, and Integrated Islamic Schools in Indonesia", Studia Islamika, 19:1 (2012): 77-111.

------. "The Salafi Movement in Indonesia: Transnational Dynamics and Local Development", Comparative Studies of South Asia, Africa and the Middle East, 27:1 (2007).

------. Laskar Jihad: Islam, Militancy, and the Quest for Identity in PostNew Order Indonesia. New York: Cornell University, 2006.

International Crisis Group (ICG). Indonesia Backgrounder: Why Salafism and Terrorism Mostly Don't Mix. ICG Asia Report No. 83 (13 September 2004).

Jawas, Yazid bin Abdul Qadir. Amar Ma'ruf Nahi Munkar Menurut Ahlus Sunnah wal Jama'ah. Bogor: Pustaka At-Taqwa, 2009.

------. Mulia dengan Manhaj Salaf. Bogor: Pustaka At-Taqwa, 2008.

------- Prinsip Dasar Islam menurut Al-Qur'an dan As-Sunnah yang Shahih. Bogor: Pustaka At-Taqwa, 2007.

-------. Syarah Aqidah Ahlus Sunnah wal Jama'ah. Bogor: Pustaka Imam Syafi'i, 2006.

Mandaville, Peter. "Transnational Islam in Asia: Background, Typology and Conceptual Overview," Transnational Islam in South and Southeast Asia: Movements, Networks and Conflict Dynamics, ed. Peter Mandaville. Washington: NBR Project Report, April 2009.

Meijer, Roel, ed. Global Salafism. London: Hurst and Company, 2009.

Pall, Zoltan. Lebanese Salafis between the Gulf and Europe. Amsterdam: Amsterdam University Press, 2012.

Wagemakers, Joas. "A Purist Jihadi-Salafi: The Ideology of Abu Muhammad al-Maqdisi." British Journal of Middle Eastern Studies, 36:2 (2009): 281-297. 
THE CHALLENGE OF DEMOCRACY IN INDONESIA: THE CASE OF SALAFI MOVEMENT

------. "A Quietist Jihadi-Salafi: The Ideology and Influence of Abu Muhammad al-Maqdisi". Ph.D thesis Radboud Universitiet Nijmegen, 2010. 